\title{
INVESTIGATION OF FACTORS INFLUENCING THE ACCURACY OF PYRHELIOMETER CALIBRATIONS
}

\author{
Philip D. Thacher, William E. Boyson, and David L. King
}

Sandia National Laboratories, Albuquerque, NM 87185

\begin{abstract}
The accuracy of solar cells calibrated as primary reference cells is directly dependent on the accuracy of the pyrheliometer used to measure the direct beam solar irradiance on the cell. Pyrheliometers are also used in measuring performance of concentrating photovoltaic modules. In order to reduce errors in photovoltaic performance measurements, we have investigated the calibration uncertainties for pyrheliometers from two manufacturers. Our calibration comparisons are relative to an absolute cavity radiometer traceable to the World Radiometric Reference. This paper quantifies the effects of aging, temperature, time-rate-of-change of temperature, wind, solar spectral shifts, linearity, window transmission, and solar tracking on pyrheliometer calibrations. Uncertainty remaining after accounting for these factors is $0.8 \%$ at the 2 -sigma level.
\end{abstract}

\section{INTRODUCTION}

Calculation of the efficiency of solar cells requires independent measurements of the solar irradiance and of the cell's output energy per unit area. Accurate efficiencies thus depend on accurate irradiance measurements. Assignment of an uncertainty to the solar irradiance measurement, $E\left(\mathrm{~W} / \mathrm{m}^{2}\right)$ provides the subject of this report. Such assignment of measurement uncertainty will be based on the procedure followed by the National Institute of Standards and Technology [1] and requires a careful analysis of factors influencing the measurements.

\section{PYRHELIOMETER OPERATION}

Figure 1, a schematic cross section of a pyrheliometer, is useful for explaining the operation and uncertainties of that device. Pyrheliometers track the sun in order to measure the irradiance (insolation) from the solar disk and a small angular region of sky around the sun. Light enters through the entrance window (1), which also determines the device's field of view, passes through the detector aperture (3), which defines the area of the beam, and is absorbed on the black-painted absorber (4). The absorber serves as the hot junction of the thermopile (5). A heat sink (6) serves as the cold junction. Outputs of the individual thermocouples are summed to give about a 10 $\mathrm{mV}$ output (7). The entire assembly is encased in a thermal shield (2) such that the temperature difference between the light absorber and heat sink depends on sunlight and not on wind and changes in atmospheric temperature.

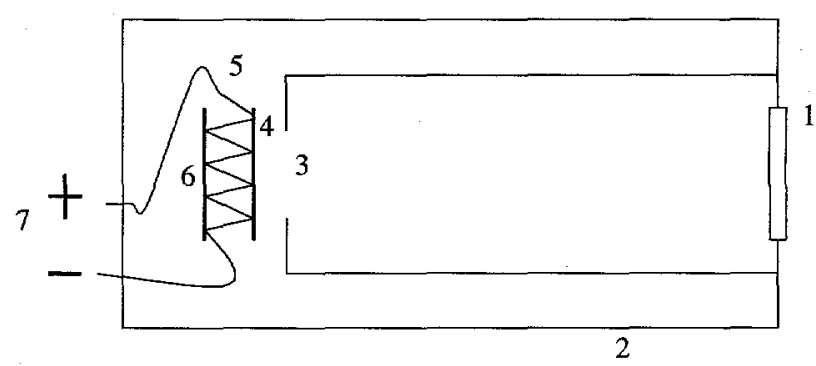

Fig. 1. Pyrheliometer schematic showing entrance window (1), thermal shield (2), detector aperture (3), light absorber (4), thermopile (5), heat sink (6), and thermopile output (7).

\section{CALIBRATION CHAIN}

Calculation of the uncertainty in irradiance measurements requires quantifiable uncertainties for the calibration chain of instruments used to measure $E$ as well as for effects such as temperature or tracking error on those instruments. The principal calibration chain is shown in Table 1 starting from the SI (International System of Units) and ending with a calibration of solar cells some 5 steps removed. This table summarizes the results of this report.

Table 1. Pyrheliometer Calibration Chain (Hierarchy).

\begin{tabular}{clcc} 
& & \multicolumn{2}{c}{ Uncertainty $(\%, \mathrm{k}=2)$} \\
Step & Calibration Level & \multicolumn{2}{c}{ Per Step / Cumulative } \\
\hline 0 & SI & $\sim 0$ & $\sim 0$ \\
1 & WRR & 0.3 & 0.3 \\
2 & TMI & 0.25 & 0.4 \\
3 & Reference Pyrheliometer & 0.5 & 0.6 \\
4 & Working Pyrheliometer & 0.5 & 0.8 \\
5 & Concentrating PV Module & -- & --
\end{tabular}

WRR refers to the World Radiation Reference maintained in Switzerland for solar measurements, and TMI refers to Sandia's Technical Measurements Inc. electricallycalibrated absolute-cavity solar radiometer that is calibrated against the WRR during periodic intercomparisons at NREL. The uncertainty per step in the table refers to the $k=2$ uncertainty accrued by the 


\section{DISCLAIMER}

This report was prepared as an account of work sponsored by an agency of the United States Government. Neither the United States Government nor any agency thereof, nor any of their employees, make any warranty, express or implied, or assumes any legal liability or responsibility for the accuracy, completeness, or usefulness of any information, apparatus, product, or process disclosed, or represents that its use would not infringe privately owned rights. Reference herein to any specific commercial product, process, or service by trade name, trademark, manufacturer, or otherwise does not necessarily constitute or imply its endorsement, recommendation, or favoring by the United States Government or any agency thereof. The views and opinions of authors expressed herein do not necessarily state or reflect those of the United States Government or any agency thereof. 


\section{DISCLAIMER}

Portions of this document may be illegible in electronic image products. Images are produced from the best available original document. 
calibration involved in that step as well as the uncertainty arising from use of the calibrated device. ( $k=2$ is roughly equivalent to a 2-sigma level of confidence or $95 \%$.) Cumulative uncertainty at a step is the root-sum-ofsquares (RSS) of uncertainties for the step in question and the preceding step. This report is restricted to factors influencing uncertainties associated with the calibration and use of the reference pyrheliometer in Step 3 and the working pyrheliometer in Step 4. Other instruments calibrated in Step 4 include pyranometers (for use with non-concentrating PV modules) and photovoltaic reference cells (for all PV Modules). Calibration uncertainties of these pyranometers and reference cells are discussed elsewhere [2,3]. Uncertainty in Step 1 comes from [4], and that for Step 2 from [5].

\section{FACTORS INFLUENCING UNCERTAINTYY}

The uncertainty of a pyrheliometer reading depends not only on the instrument's calibration but also on a large number of factors influencing that reading. Relevant factors are listed below.

1) Temperature (of the instrument's thermopile; usually recorded as ambient air temperature)

2) Rate of change of heat sink temperature

3) Thermal acclimatization

4) Time constant (of thermopile for a step change in irradiance)

5) Voltmeter calibration and drift (for both calibration and measurement)

6) Thermocouple effects (in connections)

7) Wind speed (and likely direction)

8) Solar tracking error

9) Window cleanliness

10) Field of view

11) Circumsolar radiation (aureole)

12) Window spectral transmission

13) Absorber spectral reflectance

14) Spectral content of irradiance

15) Linearity

16) Long-term stability (aging)

These factors will be briefly discussed for the two types of pyrheliometer in use at Sandia: an Eppley Model NIP and a Kipp \& Zonen Model $\mathrm{CH} 1$ [6]. Uncertainties will be quoted at the 2-sigma level.

1) Temperature. The pyrheliometer's thermopile output depends on the thermopile temperature and a thermal compensation circuit used to bound the variability to $\pm 1 \%$ over the interval of $-20^{\circ} \mathrm{C}$ to + $40^{\circ} \mathrm{C}$. Numerous calibrations on the two types of pyrheliometer over the year allowed development of temperature correction equations that compensate for thermal effects to about $\pm 0.1 \%$. Figure 2 shows the result of winter through summer calibrations for six clear days. Drift during a day is found to depend not only on temperature but also on the solar irradiance spectrum as discussed in 14).

RECEIVED OCT 042000
2) Temperature change rate. The $\mathrm{CH}$ 1s were purchased with a Pt-resistance thermometer to monitor thermopile (heat sink) temperature. The rate of change of temperature was found to affect the thermopile output over times on the order of minutes. The rate observed for the $\mathrm{CH} 1$ also applied to nearby NIPs not equipped with temperature sensors. Observation shows this effect to be bounded by $\pm 0.15 \%$; and, following [1], the bounds are multiplied by $2 / \sqrt{3}$ to obtain equivalent 2 -sigma limits of $\pm 0.17 \%$. This conversion of bounds to 2 sigma limits is used throughout this report. The rate correction is made only for the calibration in Step 3.

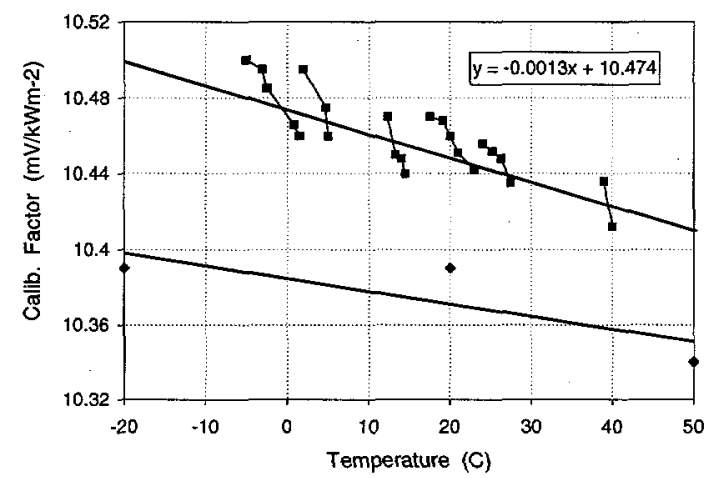

Fig. 2. Measured temperature dependence of a pyrheliometer calibration factor for six clear days, including an estimated trend line. Three diamonds show the manufacturer's relative data for the same instrument.

3) Thermal acclimatization. If the indoor storage temperature of a pyrheliometer is considerably different from the ambient air temperature, the pyrheliometer can easily read 2-3\% wrong when first placed outdoors. Measured data should be used no sooner than 1-2 hours after mounting the instrument outdoors.

4) Time constant. The time to reach equilibrium after a step change in irradiance for the TMI, CH1, and NIP is about $60 \mathrm{~s}, 10 \mathrm{~s}$, and $5 \mathrm{~s}$, respectively. Measurements for Step 3 in the calibration chain must therefore be accomplished with a "quiet" sky to keep uncertainties within $\pm 0.1 \%$, and multiple data points must be taken to average out lagging behind of the slower instruments. Time constants also affect Steps 5 and 6.

5) Voltmeter. The instrument used for pyrheliometer readout must have a calibration that is valid over its interval of use. Uncertainty in Sandia's voltmeter is $\pm 0.05 \%$ over its 6 -month calibration interval for anticipated pyrheliometer outputs of $2-20 \mathrm{mV}$.

6) Thermocouple effects. The various connections between pyrheliometer and voltmeter can give rise to thermally-induced voltages easily amounting to $0.1 \%$ for $\mathrm{a} \mathrm{Cu}-\mathrm{Pb} / \mathrm{Sn}$ (solder) junction to $>1 \%$ for a $\mathrm{Cu}-$ 
CuO (oxidized copper) junction. Good $\mathrm{Cu}-\mathrm{Cu}$ contacts are required to minimize inadvertent thermoelectric voltage contributions.

7) Wind. Tests with the $\mathrm{CH} 1$ wrapped in foam showed wind to have little effect on the output. The NIP shows about a $-0.15 \% / \mathrm{m} / \mathrm{s}$ effect on wind speed as measured with an anemometer having a $15-30 \mathrm{~s}$ time constant. The effect, however, is not clear-cut, especially for typically variable wind speed and direction.

8) Tracking error. When tracking pyrheliometers according to manufacturer's specifications $\left( \pm 0.75^{\circ}\right.$ for the $\mathrm{CH} 1$ ), the $\mathrm{CH} 1$ output varies about $\pm 0.05 \%$, and the NIP varies by perhaps $\pm 0.2 \%$.

9) Window cleanliness. Window cleanliness is the most important factor to be recognized when making irradiance measurements. We have cleaned an already apparently clean window and found the output to increase by $0.3 \%$ and then agree with previous data. Windows that look only mildly dirty can easily be absorbing or reflecting a few percent of the incoming light. Similarly, condensation on the window's inside surface must be eliminated by removing the window and drying the pyrheliometer.

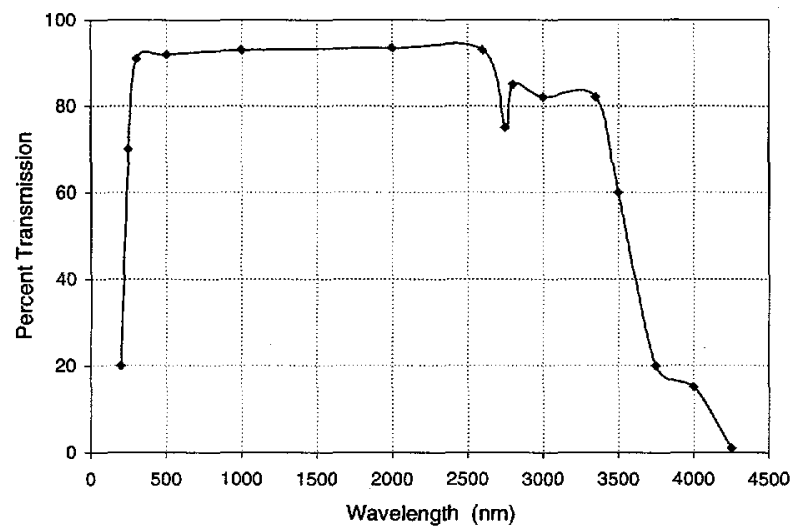

Fig. 3. Spectral transmission of $10-\mathrm{mm}$ thick Infrasil (quartz glass). Pyrheliometers use 1-2 $\mathrm{mm}$ Infrasil entrance windows. Reflection losses are included in the data.

10) Field of view. Full-angle fields of view for the TMI, $\mathrm{CH} 1$, and NIP are $5.0^{\circ}, 5.0^{\circ}$, and $5.7^{\circ}$ respectively, and the slope angles between the detector and viewlimiting apertures are $0.8^{\circ}, 1.0^{\circ}$, and $1.8^{\circ}$. The intensity and spectral distribution of the solar aureole (circumsolar radiation) will thus affect the NIP differently from the TMl and $\mathrm{CH} 1$. See 11).

11) Aureole. Irradiance of the solar aureole will affect the $\mathrm{TMl}$ and $\mathrm{CH} 1$ the same way because of their similar construction. Extra aureole seen by the NIP relative to the TMI leads to a variability about the TMI value estimated in Ref. [6] as $\pm 0.1 \%$. Clear skies were assumed for this calculation.

12) Window spectral transmission. Infrasil (fused quartz) windows are used on both pyrheliometers. These windows transmit essentially all the solar ultraviolet reaching the earth, with the low-end cutoff starting about $270 \mathrm{~nm}$. The infrared cutoff starts at about $2500 \mathrm{~nm}$ and completely cuts off above 4300 $\mathrm{nm}$. Reflection losses slowly decrease over the pass band because the refractive index decreases with increasing wavelength. See Figure 3.

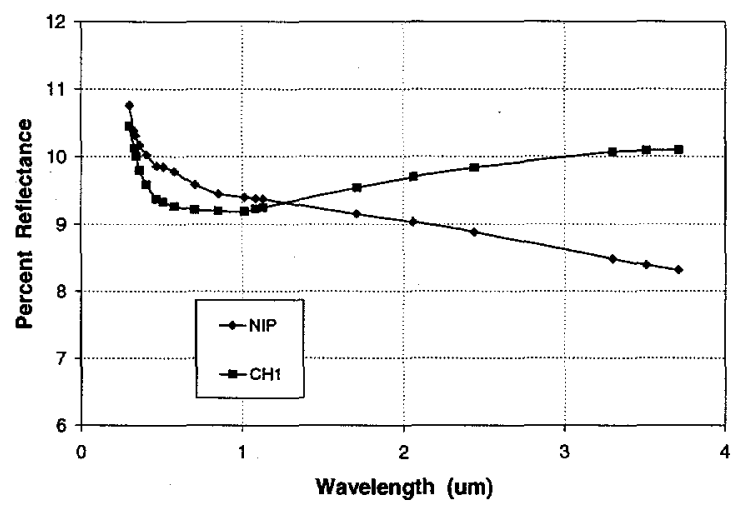

Fig. 4. Total spectral reflectance of the NIP (lower points at higher wavelengths) and the $\mathrm{CH} 1$. Data include both reflectance of the black absorbing coating on the thermopile hot junction and the reflectance of two Infrasil surfaces.

13) Absorber spectral reflectance. Thermopile absorptive coatings of carbon black used in the $\mathrm{CH} 1$ and the 3M Flat Black [7] used in the NIP both reflect more in the UV, but at longer wavelengths the $3 \mathrm{M}$ black drops down and stays level over the window's pass band whereas the carbon black drops and then rises again.

14) Irradiance spectrum. As the spectral content of the solar irradiance varies due to changes in air mass, water vapor, haze, etc., the two pyrheliometer models will exhibit the same window losses but slightly different absorber reflectances. The net result is a slight sensitivity to the spectral content of the solar irradiance. However, the TMI absolutecavity radiometer used to calibrate the pyrheliometers has both no window at all and an almost perfectly absorbing light trap. As a result, changes in the spectrum of light are measured equally well, and infrared light beyond the window cutoff is also measured. These effects are still under investigation as the most likely cause of the apparent variation of the pyrheliometer's calibration factor with air mass shown in Figure 5 . Until this issue is settled, an observed uncertainty of $\pm 0.3 \%$ will be used to cover spectral effects in steps 11 through 14. 


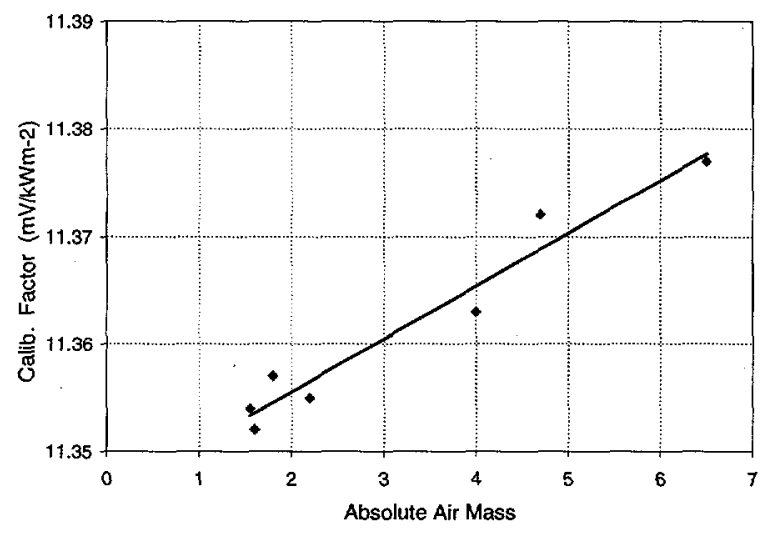

Fig. 5. Variation of the pyrheliometer calibration factor with absolute air mass on a clear winter morning. Ambient temperature was $0^{\circ} \mathrm{C}$.

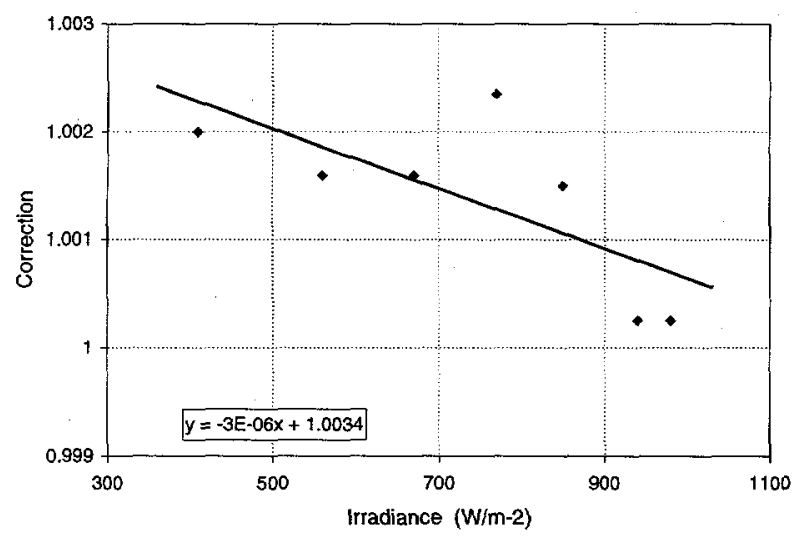

Fig. 6. Linearity correction to the calibration factor, or, perhaps, a residual effect of atmospheric attenuation.

15) Linearity. Tests of the NIP relative to the TMI over the solar irradiance interval $400-1000 \mathrm{~W} / \mathrm{m}^{2}$ were within $\pm 0.1 \%$ on one afternoon with very stable atmospheric conditions: no clouds or haze, ambient temperature constant within $1^{\circ} \mathrm{C}$, and wind constant at about $1 \mathrm{~m} / \mathrm{s}$. Morning data were not used because long experience has shown morning calibrations to drift down substantially - perhaps affected by changes in spectrum and temperature. See Fig. 6. The $\mathrm{CH} 1$ has not been so tested

16) Aging. Starting $2-3$ years after manufacture, we have calibrated our NIP against the TMI radiometer at least once per year for the past 18 years. No drift relative to the TMI has been noted within the $\pm 0.2 \%$ precision of the calibrations, and no absolute drift in calibration has been observed that is greater than the $\pm 0.6 \%$ calibration accuracy. The NIP did lose its exterior paint during 20 years of continuous outdoor fielding, but such loss appears not to have affected the calibration.

\section{SUMMARY}

RSS combination of the uncertainties due to the factors just discussed amounts to about $\pm 0.5 \%(k=2)$ for both pyrheliometer models. This uncertainty is entered into the calibration-chain table for pyrheliometer Steps 3 and 4 . Note that the uncertainties in that table hold for exacting calibrations and the most careful control over the factors influencing uncertainty - including a stable sky. Even so, the uncertainty of a well-calibrated working pyrheliometer is only marginally better than the $\pm 1 \%$ generally claimed for these devices.

\section{REFERENCES}

[1] B. N. Taylor, and C. E. Kuyatt, "Guidelines for Evaluating and Expressing the Uncertainty of NIST Measurement Results", NIST Technical Note 1297, 1993.

[2] D. I. Wardle, L. Dahlgren, K. Dehne, L. Liedquist, L. J. B. McArthur, Y. Miyake, O. Motschka, C. A. Velds, and C. V. Wells, "Improved Measurement of Solar Irradiance by Means of Detailed Pyranometer Characterization", International Energy Agency Report IEA-SHCP-9C-2, 1996.

[3] C R. Osterwald, et al., "The World Photovoltaic Scale: An International Reference Cell Calibration Program," Progress in Photovoltaics: Research and Applications, Vol. 7, No. 4, 287-297, 1999.

[4] C. Frölich, "History of Solar Radiometry and the World Radiometric Reference", Metrologia 28(3), 111-115, 1991; and references therein.

[5] Based on unpublished NREL reports of pyrheliometer comparisons in 1996 and 1998.

[6] P. D. Thacher, "Precision and Accuracy Improvements to the Technical Measurements, Inc. Solar Radiometer System," Sandia Report SAND81-0073, 1983; and references therein.

[7] Mention of a company product implies no endorsement by Sandia National Laboratories nor lack of a suitable substitute.
Sandia is a multiprogram laboratory operated by Sandia Corporation, a Lockheed Martin Company, for the United States Department of Energy under contract DE-AC04-94AL85000. 